UDC.537.523.3

\title{
コロナ放電におけるイオン電流分布の 相似性についって
}

$\begin{array}{llll}\text { 東京大学 } & \text { 増 田 閃一 } \\ \text { 東京大学 新 岡 正 樹 }\end{array}$

\section{1.はじめに}

電気集じんではコロナ放電によってダストの荷電が 行なわれている。この場合，ダスト粒子の理論飽和電 荷量 $Q_{\infty}$ 惊粒子が球形でての半佳 $a$ が(1) $a \geq 1 \mu \mathrm{m} の$ 場合，コロナ空間の電界 $E$ に比洌するとともに，荷 䉓に要する時間（荷電時定数で表現）てはイオンの電 荷密度 $\rho_{i}$ に反比例し，また(2) $a \leq 0.1 \mu \mathrm{m}$ のときは $Q_{\infty}$ は $E, \rho_{i}$ K無関係となるが， $\tau$ は $\rho_{i}$ に反比例す ることが知ら㧈ている(1)。ところで荷電空間に枋ける 電極系としては，通常ロッドに一定間隔で針在植えれ んだ針付ロッド対平板電極や針金対平板電極が用いら れる。この場合，コロナ放電の発生様態は前者の電極 系ではすちろん点状となるが，娞者の場合です負コ口 ナ在使用する限りは*, コロナは放電線上汇ある間融 をるって点状に発生することが知られている。このよ うにコロナが点状に発生する結果乙して，荷電空間に は必然的にイオンのデッドスペース（ $\rho_{i} \simeq 0$ の場所） が生ずることとなるが，筆者らはこれが荷電効率の低 下をもたらすことを確認しだ22。

一方，電気集じん装置の性能を低下ざせる異常現象 として,逆電蜼現鼠とダスト再我散現象とがあるが。 れらはと毛にダストの電受抵抗率 $\rho_{d}$ と策じん極上の 負イオン電流密度化よって左右されることが知られ ている。すなわち，i×のdが小さくなり過ぎると集じ ん極上にたい積したダスト㽫に電気的付着力が働かな くなると同時に, 静電䅎遒による正極性の帯電が起と

Similitude Law in Corona Current Distribution By Sen-ichi Masuda, Member \& Masaki Niioka, Member (Faculty of Engineering, University of Tokyo).

增田际一：正員，東京大学

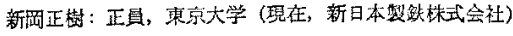

昭 $51-9$

\section{論 文 51-A 53}




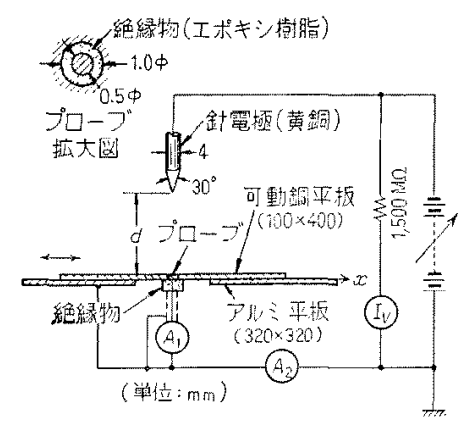

第 1 因平板上需流密度分有の測定装置

Fig. 1. Probe method for the measurement of current density distribution upon the plate electrode.

して実駩を行なっだ。本研究で用いた平板上のイオン 霞流密度分布の測定装䇫を第 1 図に示す。電流密度の 湘定は，困に示されるようなプローブによって行なっ た。電流密度 $i$ の算出にあたっては，A1 による測定 電流 $I_{A_{1}}$ をプロープの有効面皘で割ればよいが，プロ 一ブには籍気力線が集中するので，その有効直径は $0.58 \mathrm{~mm}$ であった。この有効直軽は $I_{A_{1}}$ の測定值を平 板 $S$ 上にわたって積分した值 $\int_{S} I_{A_{1}} \cdot d s$ と全電流 $I_{A_{2}}$ の測定檤己を比較することにより決定した。この有效 直径を用いて $i$ を平板上で積分して求めた全電流の值 は，その声接测定值 $I_{A z}$ とすべての测定において \%め内の精度で一致した。この誤差は测定プローブの 移動化伴う横方向一の病移や積分浊差によるものと思 われる。簕流 $I_{A_{1}}$ の湘定值は $0.2 \sim 200 \mathrm{~m} \mu \mathrm{A}$ 已極好て 微少であったため，漂遊イオン電流による誤差圭生じ やすく，乙れを完全に防ぐには平板電極の直下に電流 計 $A_{1}$ を罭き，加つ,これに至るまでの経路完全に シールドする必要があった。

\section{$\langle 2 \cdot 2\rangle$ 針 1 本対平板電極における電流密度分布}

まず，第 1 图に示されたような針 1 本対平板電極の 電極系に招いて，電極間距離 $d$ 在 $1 \mathrm{~cm}$ 加 $10 \mathrm{~cm}$ ま

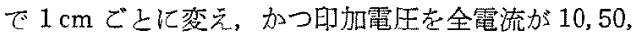

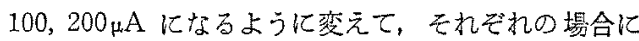
拈り万真コ口十の平板上電流密度分有を求如た。第 2 図はその結果の一例で， $d=2 \mathrm{~cm}$ 㕲よび $10 \mathrm{~cm}$ のると で全電流Iを上記の各值にした場合の板上の針直下位 置を原点とし，それからの距離 $x$ に対する板上電流密 度iの変北をプロットしたものである。ただし， $x$ 方 问の距離については電楆間距離 $d$ で基準化し，電流密 展iについてはその最大值（すなわち $x=0$ での電流 密度值） $i_{p}$ で基準化してプロットしてある。このよう な基準化走行なうと電極間距離 $d$ 拈よび全䨓流 $I$ を大

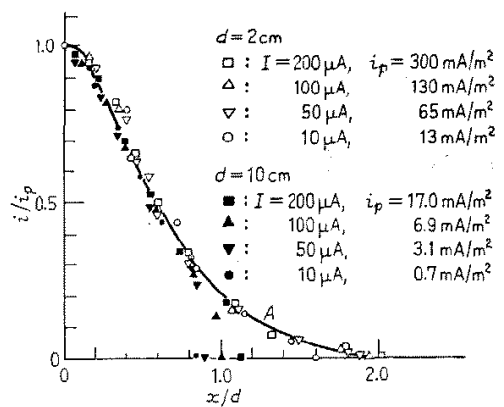

第 2 图針 1 本対平板電極に戈りる平板上 電流密度分布 $(I)$ ( $d$ を一定としI を変化させた場合)

Fig. 2. Current density distribution upon the plate electrode in the case of single. needle to plate electrode system. (I),

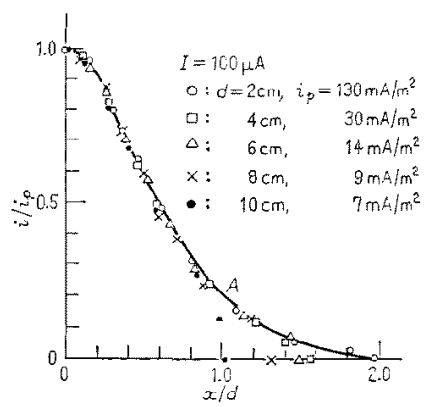

第 3 図 針 1 本対平板電極における平板上 電流密度分布 (II) ( I を一定としd を変化させた場合)

Fig. 3. Current density distribution upon the plate electrode in the case of singleneedle to plate electrode system. (II).

きな範围にわたって変えたにもかかわらず，平板上に 拈げる電流密度分布のパターンは周辺部の：の小さな 領域 $\left(i / i_{p}<0.2\right)$ を除いてはほとんど变化しないこと がわかる。更に電栖間距嚾 $d$ を $2 \mathrm{~cm}$ および $10 \mathrm{~cm}$ 以 外の上記の各值に変えて同じ湘定を行なったよころ， そのすべての堭合について同じ結果が得られ，しかも そのパターンが相互に良く一致するととが見いだされ to

第3 図は全電流 $I$ を $100 \mu \mathrm{A}$ に保ってdを変えた場 合の平板上電流密度分布を第 2 図上同じく基準化して 表わしたものである。との場合にも，iの小さな領域 (i/ $\left.i_{p}<0.2\right)$ 点除いては電流密度分布のパターンが良く 一致している。との場合についても $I$ を 100kA 以外 の各值に設定して行なった同様の測定について同じ結 果が得られ，かつこ扎らパターン相互の良い一致が見 られた。第 2 図抢上び第 3 図の曲線 $A$ は得られたすべ 
ての測定値を総合して描いた電流密度分布の代表曲線 である。てのように全電流を变えても，電極間距離を 変えてもdで基準化された $x$ 座標についての $i_{p}$ で基

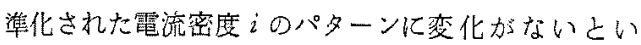
うことは, 上記電極系でのコロナ放電に晾ける平板電 極上の電流密度分布のパターンと電極心幾何学的形状 との問に相似則が成立しているととを示している。第 2 図，第3図の周辺の活ほ $i / i_{q}<0.2$ の領域での電流 密度分布のパターンには不一致が見られる。その理由 は明らかでないが， $d$ を变える際に電極の幾何学的な 形状を完全に相似に保つことができなかったととによ るものではないかと思われる。すなわち、dを增した 場合には釷電極の直径や先端の曲率半径を相似的に 增さなければ電極を完全に相似したことにはならない が，乙の場合は同に゙針電極索使用してdのみを增して いるため，相詨的に針を細くしていったてとになり， てれがほほ $i / i_{p}<0.2$ の領域でのパターンの差罢の原 因になっているものではないか子考穴ら机る。

以上のこと加ら，空間婂和るる電流密度の分布にも また，相泤則が成立していることが予想される。

\section{$\langle 2 \cdot 3\rangle$ 針 2 本対平板電極における電流密度分布}

次に，隣接点るコロナ点加らのイオン電流の影響を 調べるために放電極を 2 本にして平板上の電流密度分 布を測定した。針電極は第 4 図の上うに距離 $l$ を隔て て互いに平行に保ち，山dが一定に保た机るように， $l, d$ の值变えて平板電極上の電流密度分布意測定し た。第 5 图は $l / d=1, I=100 \mu$ A とした場合の測定結 果老前と同様の力法でプロットしたものでややは䉓 流密度分布のパターンに相似則が成立していることが わかる。また，この場合化つても全電流 $I を 100 \mu \mathrm{A}$ 以外の各值代設定してdを变えつつ测定したところ, やはり板上電流密度分布のパターンが变わらないこと 加磼加ら机た。更に， $l / d=0.3,0.375,0.5,0.75$, 1.5,3.00各場合についても相似則方成立することが 確認さ机た。

$\langle 2 \cdot 4\rangle$ 針付ロッド対平板電極における電流密度分 布最後に紫祭の電気集じん畒でよく使用されて いる針付ロッド対平板電極化お行る平板上の負コロナ 電流密度分布荧測定した。第6 図に使用した針付ロッ ド電極を示す。この埸合，板上電流密度分布に最も大 きな影稫を与无るのは針間隔 $l$ 之電極間隔 $d$ の比 $l / d$ 之考党られるか，このほ加に口ッド電極の影繁を無視 するこよはできない。促って, 相似則の成立を調べる にはld のに放 $a: b: c: l: D$ D法比をむできる だけ一定に保って露極系の相似性老保持しなければな らない。第6图中の表は便用した 3 とおりの針付ロッ

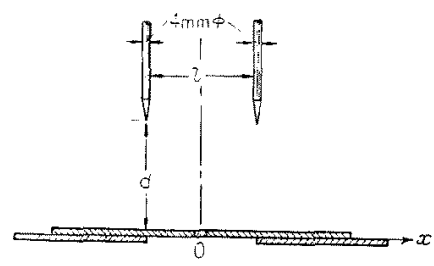

第 4 図 針 2 丛対平板霄極の構成四

Fig. 4. Construction of twin-needle to plate electrode system.

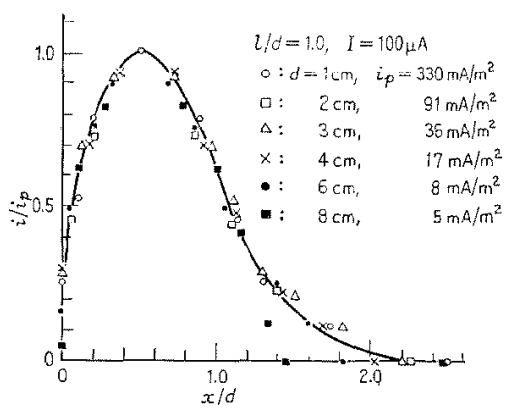

第 5 图針 2 本対平板電極伒お汀る平板上 電流密度分布 ( $l / d$ および I を一定 とし，l,dを変化させた場合）

Fig. 5. Current density distribution upon the plate electrode in the case of twinneedle to electrode system.

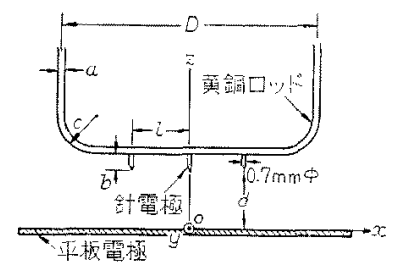

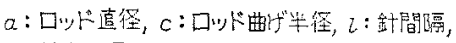

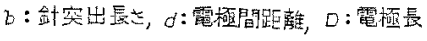

第 6 图針付口ッド対平板露極の構成図

Fig. 6. Construction of the barbed rod to plate elecrode system.

ドの寸法で，不完全ながらこの条件老满たすよう亿努 めたものである。針間隔 $l$ 子針突出長 $b$ 比は板上電 流密度分布比影響をすつすのと考光られるので， の值は活实用の放電極での值である7.5 12 の䇢 因に選んだ。

第 7 図に上記 3 種類の電極を用い， $d$ 变えて $l / d$ $=3 / 4$ 一定とした場合の $I=50 \mu \mathrm{A} お よ ひ ゙ ~ 100 \mu \mathrm{A} に$ 対 する平板上の電流密度分布を示す。この場合, ロッド 電極や隧接する針電極の影響て符 6 图の $x$ 方向上 $y$ 方 向とでは分布のパターンが異なるので，第 7 四( a ) 


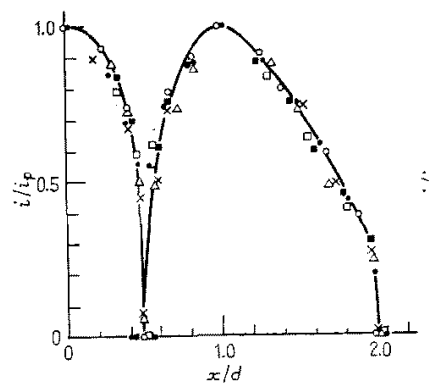

(a) $x$ 軸上の分布

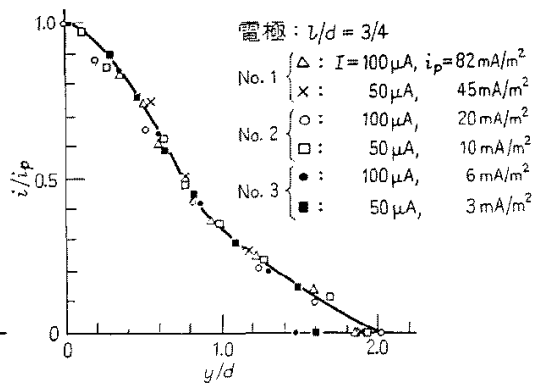

(b) y䩜上の分布

第 8 図 針付口ッド対平板電極代おりる平板上電流密度分布（I）

( $l / d$ および $I$ を一定とし， $l, d$ を変化させた場合)

Fig. 7. Current density distribution upon the plate electrode in the case of barbed rod to plate electrode system-(I).

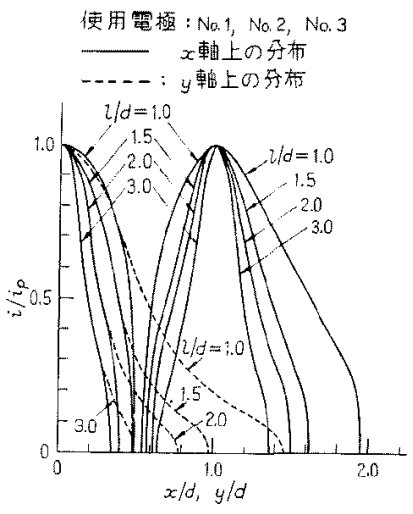

第 8 园 針付ロッド対平板電極における平 板上電流密度分布 (II)（種々の $l / d$ に対与る相倾則)

Fig. 8. Current density distribution upon the plate electrode in the case of barbed rod to plate electrode system-(II).

は $x$ 軸上のパターンを，第7四（b）には $y$ 軸上のパタ ーンを示す。このように針付ロッド対平板電極の墂合 にも基準化した電流密度分布は 部尔を除いては，l/dを一定に保古，加つ電極の寸法比

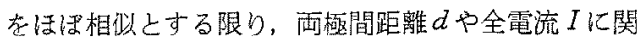
係なく等しくなって，やはり電流密度分右に相似則が 成立することが確加められた。またとの場合，平板上の イオン電流の $y$ 方向の分布はこ机垂直な $x$ 方向の分 有に比べて、かなりの広がりを示すことが認められた。 第 8 图流 $l / d=1.0,1.5,2.0,3.00$ 場合の相似則在 代表する $x$ 軸上拉よび $y$ 軸上の曘流密度分布曲線であ る。図に見られるように $/ / d>3 / 4$ となると、平板上に $i=0$ となる创域が現犼てくる。め上のように相似 則が成立する见上，電流密度分有の上で最香望ましい

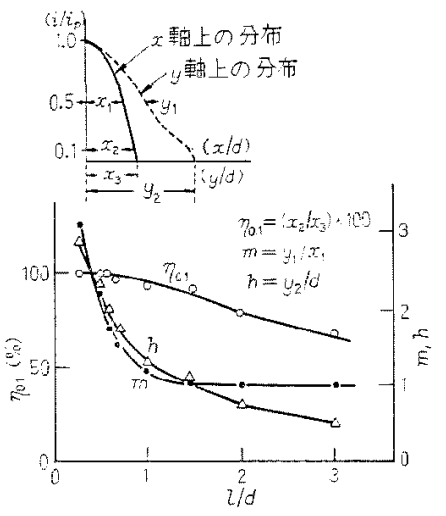

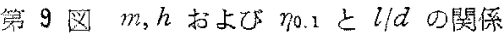
Fig. 9. The values of $m, h$ and $\eta_{0.1}$ as a function of $/ / d$.

電極構造定めるには，寸法比 $l / d の$ 違う幾種類かの 電霂パターンについて相互比晬な行なえぱ十分で，実 寸法在変化させてその影響を調べる必要がなくなる。

第9図は針付口ッド対平板電極におけるイオンカー テンの良さ示す指標として，図示の綐横の広がりの 比 $m=y_{1} / x_{1}, y$ 朝上の広がり幅 $h=y_{2} / d, x$ 軸上て $i$ $>0.1 i_{p}$ とる部分, すなおち粉体再飛散す可こ之 なく有効に保持できると考えられる部分*の割合 $r_{0.1}$ をとり，これら汃電極の幾何学パターンl/dによって どのように変わるかを示したものでる。奏際の電気 集じん装置に奏用されている針付口ッド対平板電極に おいては $l / d=0.5 〜 0.7 に$ 選ばれているが，乙れは上 記の指標 $\eta_{0.1}$ か 100\% からやや下がり始かる所に市 たっており，加つ指標hについてすy方向の方速度

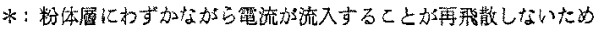

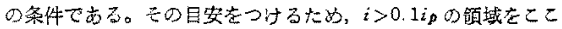
ではよるとととした。
} 
が $1 \mathrm{~m} / \mathrm{s}$ 程度で粒子が板上に分散捕集されるすのと想 定した場合には十分保持可能な值（すなわち，ダスト が通常の集じん速度で平板に達した場合，i=0よなっ ていない)となって招り，結果的には実際に用いられ ている設計値は合理的な値の範囲に選ばれることがわ 加た。

\section{3. 緩和法によるイオンカーテンの計算}

前章の結果加ら，空間に拈ける電流密度分布之電極 の幾何学的形状との間にも相似則が成り立つことが予 想される。しかしながら，すでに述べた上㧍り二次元 的な空間以外の空間でのコロナ電流密度分布の測定に は多くの因難が伴うので，ここでは針 1 本対平板電極 の場合について，緩和法により空間でのコロナ電流密 度分布を計算し，乙れ加ら空間電流密度分布之電極の 幾何学的形状との間の相似則の成立を調へることとし た。

〈3.1〉 ポアソン方程式の近似解 まず，両電極 間の空間にイオンのない場合の静電界(ラプラス笔界) を求く。

針対平板電極の作るラプラス電界は，針を次式で与 兑られる回転双曲面

$$
-\frac{x^{2}+y^{2}}{d^{2} \tan ^{2} \theta_{0}}+\frac{z^{2}}{d^{2}}=1
$$

$d$ : 電極間距離, $\theta_{0}$ : 渐近線の傾斜角

で近似するととに上り，解析的に求めら扎る(5)。する わち, 長軸回転だ円面座標 $(\alpha, \beta, \varphi)$

$$
\begin{aligned}
& x=c \sin h \alpha \sin \beta \cos \varphi \\
& y=c \sin h \alpha \sin \beta \sin \varphi \\
& z=c \cosh \alpha \cos \beta
\end{aligned}
$$

を用いればポ゚テンシャルфは

$$
\phi=\frac{V_{0}}{\ln \left(\cot \frac{\theta_{0}}{2}\right)} \ln \left(\cot \frac{\beta}{2}\right)
$$

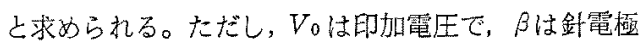
面では 0 ，平板電極面では $\pi / 2$ をとる。

次に電極間に空間電荷吕存在するコロナ空間の電界 㹥次のポアソン方程式を満足する。

$$
\operatorname{div} \boldsymbol{E}=\rho / \varepsilon_{0}
$$

ただし， $\boldsymbol{E}$ は空間に扔的る電界強度っ○は空間電荷 密度である。との場合のは定常状態では電流連続の式

$$
\operatorname{div} \boldsymbol{i}=\operatorname{div}(K \rho \boldsymbol{E})=0
$$

$K:$ インン移動度

を満足するような分布をとる。従って、コロナ空間の

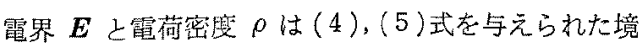

界条件のあとに解けば求るられることになる。

(4) 式をポテンシャル $\phi$ に関して円筒座標 $(r, \theta, z)$ で表わすと

$$
\left.\begin{array}{l}
\frac{\partial^{2} \phi}{\partial z^{2}}+\frac{1}{r} \frac{\partial \phi}{\partial r}+\frac{\partial^{2} \phi}{\partial r^{2}}=-\frac{\rho}{\varepsilon_{0}}(r \neq 0) \\
\frac{\partial^{2} \phi}{\partial z^{2}}+2 \frac{\partial^{2} \phi}{\partial r^{2}}=-\frac{\rho}{\varepsilon_{0}}(r=0)
\end{array}\right\}
$$

とな゙る。とれを用い，功 $K=$ 一定として(5)式を同 じく $\rho に$ 関して円筒座標て表わすと

$$
\begin{aligned}
& \frac{\partial \phi}{\partial z} \cdot \frac{\partial \rho}{\partial z}+\frac{\partial \phi}{\partial r} \cdot \frac{\partial \rho}{\partial r}=\frac{\rho^{2}}{\varepsilon_{0}}(r \neq 0) \\
& \frac{\partial \phi}{\partial z} \cdot \frac{\partial \rho}{\partial z}=\frac{\rho^{2}}{\varepsilon_{0}}(r=0)
\end{aligned}
$$

となる。(6)式格よび(7)式加ら針対平板電極化対す るめと $\rho$ の解析的な解を得ることはできないので， 空間を格子で分割し，それらの格子点関する $\phi$ 上 $\rho$ の送次近似式を用いて各点の $\phi$ と $\rho の$ 值が收束する まで絽り返し計算を行なう，いわ酒る緩和法によって 近仪解を求めることにする。

境界に扔いては必ずしす正方格子にならないので， 第 10 因に示されるような格子点 0 亿 亿関して遂次 近似式を求就てととにする。それぞれの格子点で のポテンシャルを $\phi_{i}$, 空間電荷密度を $\rho_{i}$ 之菁くと, (6)式加

$$
\begin{aligned}
\phi_{0}= & {\left[\frac{1}{s_{1}\left(1+s_{1}\right)} \phi_{1}+\left(\frac{1}{s_{1}}-\frac{h}{2 r}\right) \frac{\phi_{2}}{1+s_{2}}\right.} \\
& +\frac{\phi_{3}}{1+s_{1}}+\left(1+\frac{h}{2 r}\right) \frac{\phi_{4}}{1+s_{2}} \\
& \left.+\frac{h^{2} \rho_{0}}{2 \varepsilon_{0}}\right] /\left(\frac{1}{s_{1}}+\frac{1}{s_{2}}\right)(r \neq 0) \\
\phi_{0}= & \frac{1}{6}\left[\phi_{1}+4 \phi_{4}+\phi_{3}+\frac{h^{2} \rho_{0}}{2 \varepsilon_{0}}\right](r=0)
\end{aligned}
$$

また（7）式加号

$$
\left.\begin{array}{rl}
\rho_{0}^{2}= & \frac{\varepsilon_{0}}{s_{1} s_{2} h^{2}}\left[\left(\phi_{1}-\phi_{0}\right)\left(\rho_{1}-\rho_{0}\right)\right. \\
& \left.+\left(\phi_{2}-\phi_{0}\right)\left(\rho_{2}-\rho_{0}\right)\right](r \neq 0) \\
\rho_{0}= & \frac{\varepsilon_{0}}{h^{2}}\left(\phi_{1}-\phi_{0}\right)\left(\rho_{1}-\rho_{0}\right)(r=0)
\end{array}\right)
$$

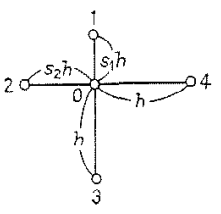

第 10 図格子点の番号

Fig. 10. Numbers of the mesh points. 
が學加れる。

境界条件としては，фに関しては釗電極上で，印加 霓压 $\phi_{0}$ ，平板電極で0に等しいよす机ばよいが，最む

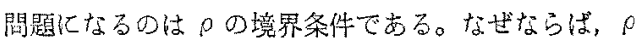
に関してはコロナ放電の物理現象に正しく刘応した境 界条件のとり方加現在のところ明らかでないからであ る。そこで，ここでは針の先端の格子点点電荷源と 考え，ここに次のような值の電荷密度 $\rho_{c}$ を与えてや ることにした。すなおち，この值 $\rho_{c}$ はある電極間原 で最終的に平板上で得られる全電流の計算值 $I$ か，さ きに求代をの電極間隔における全電流の実験值に等 しくなるよう trial and error によって求めるのであ る。格子点間隔は $h=d / 20$ とし, $z$ 方向は $2 d$ まで, $r$ 方向については $3 d$ までの空間䇲囲を考慮した。計算 にあたっては，収束を早めるためめの初期分布として (3)式のラプラス電界における中の分有をとった。ま た $\rho$ の初期分布は針の先端以外は 0 上した。遂次近似 式の繰り汳し計算数は，原則として針下の $z$ 朝上て

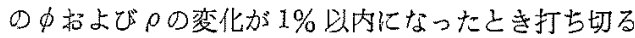
ことにしたが， めに関しては空間でのポテンシャルが 針のポテンシャルよりも大きくなるという不都合な摆 象が起きるので, 最大 10 回の繰り返し計算で $z$ 軸上 での変化が $1 \%$ 以下にならないときはそのまま計算を 打ち切っだ。

上のようなのの境界条件の上り方は，便宣的かつ实

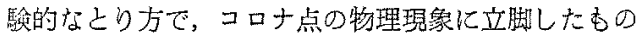
ではない。従って，与光られた $\phi_{0} に$ 対するIの值 索，こてで述べた計算手法で任意の電極系に対して求 めることは不可能である。しかし， $\phi_{0}, I$ が暨知の場 合，コロナ空間标ける $\rho, E ， i$ の分有のパターンを 求めるには，この上うな 0 の境界条件の上り方走採用 するととによる愦差は小さいすのと考えられる。なせ ならば，針の先端の一点で $\rho c$ を指定する場合と，そ
の近傍の小さなコロナ領域の外周にある分有をもって $\rho_{c}$ に相当する屯のを設定する場合上では，針先端の 近傍老除く大部分の空間領域て $\rho, E, i$ 分布に大差 が括毛の上考元られるからである。

〈3・2〉計算結果 まず,このような計算によって 得られる平板電極上の電流密度分有第 2 章の央験值 と比較して第 11 图化示吉。同図( a ) 住 $d=1 \mathrm{~cm}$ 一定 として I を変えた場合の計算結果で，計算による電流 密度分有屯Iの值関係なく同一パターン上なり，か つこのパターンは実测結果に近いあのとなっていると とがわかる。また同図(b)は $I=100 \mu \mathrm{A}$ 一定としてd を変えた場合についての計算結果であるが，同図(a) と全く同じ結果が得られた。とれらの結果加ら，計算 に上万平板上電流密度分市古やはり相似則を示すと上 もに，その分布のパターンは実测結果とほぼ一致する ことが確認された。これはまた〈3・1〉節の計算手法, 特に○の境界条件のとり方がコロナ空間におりる電界 $E$, 電荷密度 $\rho$, 従って䉓流密度 $i$ の分布求める目 的に対しては妥当であることを物語っている。第 12 図には，これらの煬合の平板電極上の基準化されな電 荷密度 $\rho$ 分布を，第 13 図《柆平板電極上の基準化 された電界強度 $E$ の分布を示す。たたし $\rho_{p}, E_{p}$ は $r / d=0$ に扔ける板上での $\rho, E$ の計算值である。第 12 図, 第 13 図に見られる上うに，諳算に上って得られ

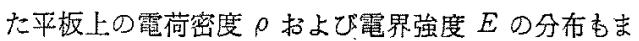
た電極形状上の間に相似則有している。第 13 図儿 は比較のため空間電荷のない場合 ( $I=0$ の場合) の平 板電極上の静電界の分布它併記したえ゙，空間電荷の存 在する場合のE/E るこ上がわかる。

そこで空間分布についてこの点艺調へるため，上述 の計算によって得られた空間飞打りるポテンシャル $\phi の$ 分布を等間電荷のない場合の静電界の $\phi$ 分布之

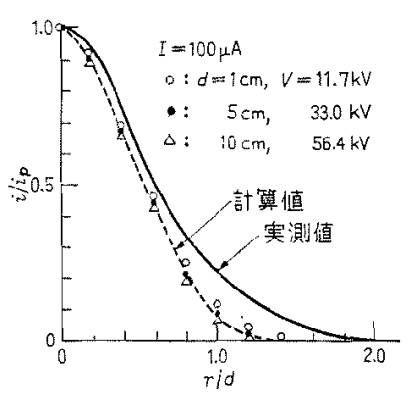

(b)I范一定としdを变化した場合

(る)光を一定としI变化しを場合

第 11 図針1本対平板雪極における年板上電流密度分布の計算值

Fig. 11. Calculated values of current density distribution upon the plate electrode in the case of single-needle to plate electrode system. 


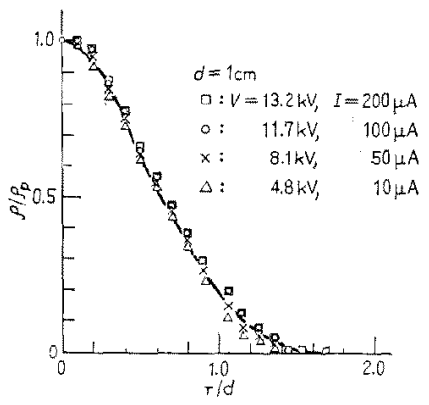

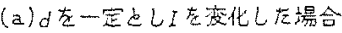

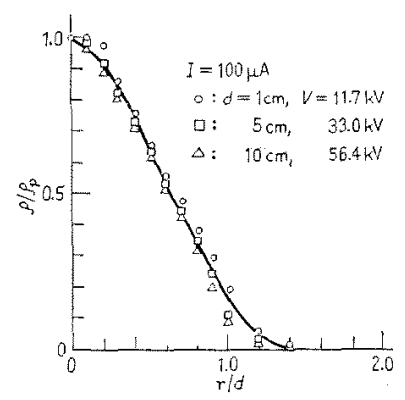

(b)I苦一定としd者变化した場合

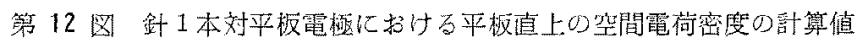
Fig. 12. Calculated values of space charge distribution just above the plate electrode in the case of single-needle to plate electrode system.

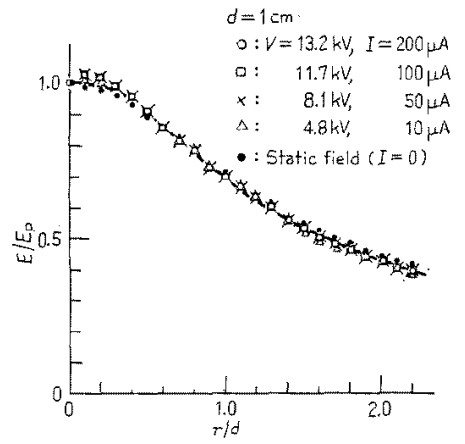

（a）dを一定过しIを变化した場含

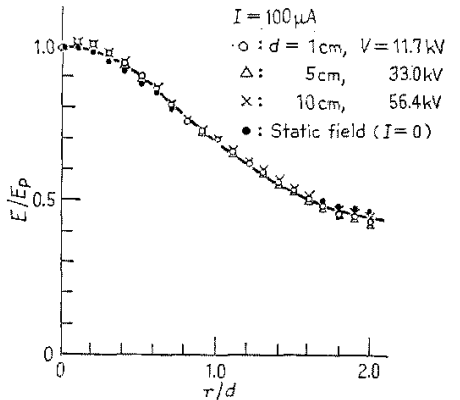

(b)I孝一定をしdを变化しを場合

第 13 図 針 1 本対平板電極比扔ける平板上電卧強度分布の計算值

Fig. 13. Calculated values of field strength distribution just above the plate electrode in the case of single-needle to plate electrode system.

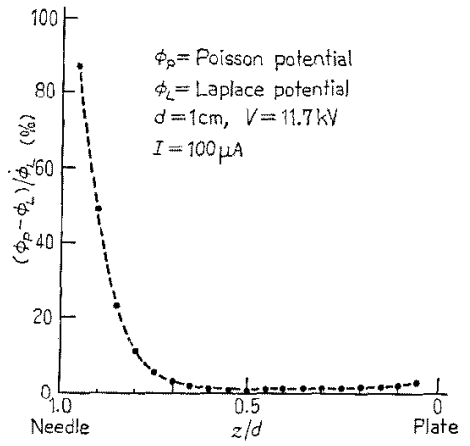

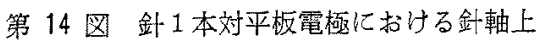
のホアソンン電位のラプラス電值に 対する偏若 (計算值)

Fig. 14. Deviation of Poisson's potential from Laplace's potential along the needleaxis in the case of single-needle to plate electrode system (calculated values).

比較した。第 14 区ばその一例で，猃軸（ $z$ 朝）上の
格子点で，(4)式の解として求めら机た゚アンンポテ ンシャル $\phi_{p} の ，(3)$ 式で与えられたラプラスポテン

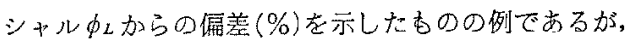
このように釗電極加ら $0.2 d$ 程度離れると偏差は数八゚ 一セント以下をなり，特に $0.3 d$ 以上離れた所では両 者は実質的にははとんよ゙一致してしまう。すなわち， 空閵電荷の影響によって電界が大きく変わいを受けて いる部分は比較的針先に近い領域のみであることがわ

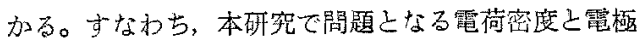

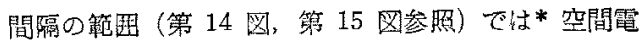
荷の影響は比較的小さく, ポアンン方程式 (4)の解は 空閏の多くの部分でラプラス方程式

$$
\operatorname{div} \boldsymbol{E}=0
$$

の解*゙とほとんど一致するとととなる。その結果，電 界強度 $E$ の空間分布に古近似的飞相似則办現われる

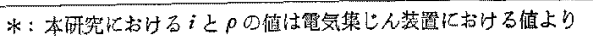
委 1 日大以上あ大寺い。

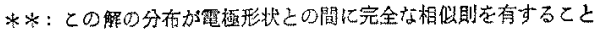
はいうをですな。
} 


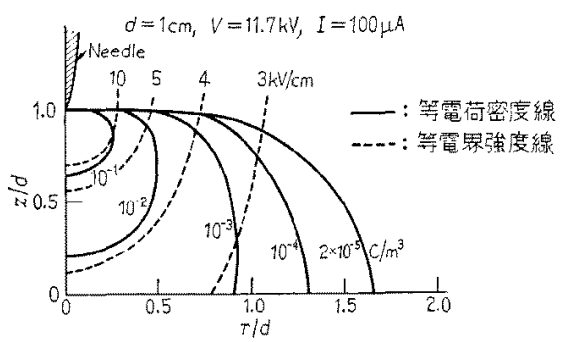

第 15 図 針 1 本対平板電極江扰ける空間 での等電荷密度線分布と等電界強度 線分布(計算値)

Fig. 15. Equi-space charge density lines and equi-field strength lines in the case of single-needle to plate electrode system (calculated results.).

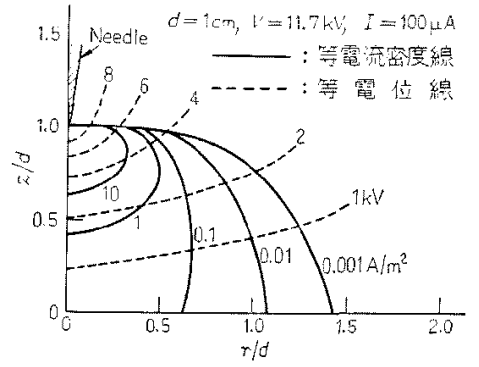

第 16 図 針 1 本対平板電極比打的空間 での等電流密度線分布之等電位線 分布(計算值)

Fig. 16. Equi-current density lines and equi-potential lines in the case of singleneedle to plate electrode system (calculated results).

結果となるととが理解できる。

第 15 図は $d=1 \mathrm{~cm}, I=100 \mu \mathrm{A}$ の場合の空間にお ける電荷密度 $\rho$ の分布之電界強度 $E$ の分布を示した おのである。 $d=5 \mathrm{~cm}$ および $d=10 \mathrm{~cm}$ で $I=100 \mu A$ の場合についてあほほ同じパターンの分布図が得ら

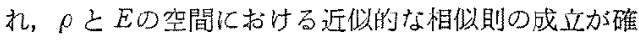
認された。乙机ら両者の筧として求められる空間机 ける電流密度分布 $i$ 上電位 $\phi \infty d=1 \mathrm{~cm}, I=100 \mu \mathrm{A}$ の場合の分布を参考のた的第 16 図に示す。 $d=1$ $\mathrm{cm}, I=10 \mu \mathrm{A}$ の場合についても $i$ の分布を求的たと ころ，第 16 図におけるをれに対して近似的に相似と なることが認如られた。

以上の計算は尃的 1 本対平板電極の場合について 行なったが，針付ロッド対平板電極については現在の
とてろ計算が困難なため，同じような結果が得られる かどうかは明らかでない。

第 15 図，第16 図加ら明らかなように，針対平板 電極の場合には針先付近の作る電界によってコロナ力 ーテンは割合に針先から側方に広がって行くことがわ 加たが，通常の電気集じん装置で使用される剑金対 平板電極や針付ロッド対平板電極でのコロナ放電にお いては，放電を行なっていない針金部分やロッド電極 から出る電気力線の影響によってコロナカーテンの側 方（第 6 図 $x$ 方向）への広がりが抑元られ，之の結果 多かれ少なかれデッドスペースが生ずるものと予想さ れる。

\section{4.むすび}

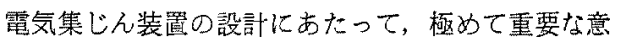
味を持つ集じん極上ならびにコロナ空間の電流密度分 布を理諭と実験の両面から研究した。 その結果,

（1）針対平板電極战よで針付ロッド対平板電極で の真コロナ放電你して, 実用上問題となる電極寸法 ならびに電圧のもとでは，平板上の電流密度分布が電 極の幾何学的パターンによってのみ決まり，その実寸 法や電流の大きさには上らないという相似則が成り立 つととを実験的に確認した。

（2）また釙1本対平板電極の埸合につき, コロナ 電界の数值計算危行なうことに上って平板の電流密度 分布の計算値にも上記の相似則が成立することを明ら かにするととすに，計算の結果加ら，との場合，平板 上のみでなく空間におりる電流密度 $i$, 電界 $E$, 電荷 密度 $\rho$ の分布にす近似的飞相似則吕成り立つことを示 した。ただし，針付ロッド対平板電極については現在 のところ計算の困難さのため計算上同じ結果が得られ るかどうか明らかでない。

(昭和 49 年 11 月 25 日受付, 同 51 年 2 月 2 日再受驸)

\section{文献}

(1) H.J. White: Trans. Amer. Inst, Elect, Engrs 76, 1186 (1951)

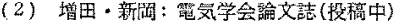

(3) P. Cooperman Trans. Amer. Inst, "Elect. Engrs 75, 64 (1956)

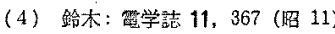

(5) P. Moon \& D.E. Spencer: Field Theory for Engineering (1961)

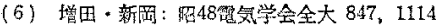

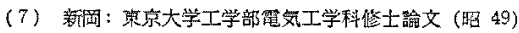

